\title{
Implementasi Nilai-nilai Pendidikan Pesantren dalam Meningkatkan Ketahanan Mental Santri
}

\author{
Muhammad Mushfi El Iq Bali* \& Mohammad Fajar Sodik Fadli** \\ Universitas Nurul Jadid Paiton Probolinggo Jawa Timur \\ *mushfieliqbali8@gmail.com \\ **fajarsodik469@gmail.com
}

\begin{abstract}
Education is the main investment in shaping a person's character, personality and mentality. In this globalization era, character, personality and mental education are eroded by western education. Islamic boarding school education is a top priority in shaping a person's character, personality and mentality to be better. Islamic boarding school education provides optimal and effective time in implementing religious and moral values. The capacity of pesantren as a religious institution in its history has succeeded in realizing the order of life of religious communities, with a fundamental and complex understanding of Islam. The values of Islamic education that are so complex from values, aqeedah, monotheism, morality and science in this era of globalization have been fulfilled in Islamic boarding schools. Therefore Islamic boarding school education applies the values of quality Islamic education to establish the mentalty resilience of santri (islamic student), Islamic boarding school plays an important role in making a person become a human who is civilized (insanul kamil).
\end{abstract}

Keywords: Implementation, Islamic Boarding Education, Islamic Student Mentalty Resistance

\begin{abstract}
Abstrak: Pendidikan merupakan investasi utama dalam membentuk karakter, kepribadian, dan mental seseorang. Pada era globalisasi ini pendidikan karakter, kepribadian dan mental terkikis oleh pendidikan barat. Pendidikan pesantren sebagai pilihan utama dalam membentuk karakter, kepribadian dan mental seseorang agar menjadi lebih baik. Pendidikan pesantren memberikan waktu yang optimal dan efektif dalam mengimplementasikan nilai-nilai agama dan moral. Kapasitas pesantren sebagai lembaga keagamaan dalam sejarahnya telah mampu mewujudkan tatanan kehidupan masyarakat yang agamis, dengan pemahaman yang mendasar dan mendalam tentang Islam. Nilai-nilai pendidikan yang begitu komplek dari nilai, aqidah, tauhid, akhlaq dan ilmu sains di era modernisasi saat ini, sudah terpenuhi di pondok pesantren. Oleh karena itu, pendidikan pesantren menerapkan nilai-nilai pendidikan Islam yang berkualitas untuk membentuk ketahanan mental santri, pesantren berperan penting dalam menjadikan seseorang menjadi manusia yang berkeadapan (insanul kamil).
\end{abstract}

Kata kunci: Implementasi, Pendidikan Pesantren, Ketahanan Mental Santri 


\section{PENDAHULUAN}

Pesantren adalah lembaga pendidikan Islam tertua di Indonesia. Kehadiran pesantren bersamaan dengan datangnya Islam, utamanya di pulau Jawa. Meski demikian pengaruh pesantren tidak banyak dibacarakan oleh berbagai kalangan karena pesantren yang cenderung eksklusif dan tradisonal. Karena itu, di era modern saat ini tantangan pesantren dalam meningkatkat kulitas sumber daya manusia semakin komplit mengingat peta persaingan menuju era digital 4.0 sangat berat. Lulusan pesantren dituntut untuk lebih baik dalam menyikapi perubahan zaman. ${ }^{1}$ Mengingat era digital 4.0 telah mewarnai seluruh aspek kehidupan masyarakat, ${ }^{2}$ sehingga memicu keseimbangan ketahanan mental seseorang. Maka, pesantren dituntut untuk meningkatkan ketahanan mental seseorang agar bisa menghadapi era digital 4.0 saat ini.

Kesuksesan pesantren dalam membina santrinya tersebut bukan suatu keberuntungan, akan tetapi ada nilai-nilai pendidikan khas yang mendasarinya. Beberapa dimensi soft yang mempengaruhi kepada sistem kinerja individu dan organisasi, yaitu nilai-nilai (values), keyakinan (belief), budaya (culture) dan tingkah laku. Nilai-nilai adalah pembentuk budaya dan merupakan dasar atau landasan bagi perubahan dalam hidup pribadi atau kelompok. ${ }^{3}$ Nilai adalah pengertian-pengertian (conception) yang dapat dihayati oleh seseorang mengenai hal yang lebih kurang penting atau penting, perihal yang kurang baik atau lebih baik dan hal yang kurang benar atau lebih benar. ${ }^{4}$

Walaupun demikian, kapasitas pesantren sebagai lembaga keagamaan dalam sejarahnya telah mampu mewujudkan tatanan kehidupan masyarakat yang agamis, dengan pemahaman yang mendasar dan mendalam tentang Islam. Perwujudan ini dapat dibuktikan melalui sistem dan proses pembelajaran yang berlangsung di dunia pesantren, yaitu dilaksanakannya berbagai proses transfer keilmuan kepada para santri

\footnotetext{
${ }^{1}$ Muhammad Mushfi El Iq Bali, 'Perguruan Tinggi Islam Berbasis Pondok Pesantren', Al-Tanzim, 1.2 (2017), 1-14.

2 Muhammad Munif, 'Pengembangan Pendidikan Agama Islam', 3.2 (2015), 46-57.

${ }^{3}$ Stephen P Robins, Perilaku Organisasi, Buku 1 dan 2, (Jakarta: PT. Prenhallindo, 1995), 81.

${ }^{4}$ Taliziduhu Ndraha, Teori Budaya Organisasi (Jakarta, PT. Rineka Cipta, 2005), 30.
} 
dengan berbagai disiplin ilmu keagamaan seperti Fiqih, Tauhid, bahasa Arab, Nahwu, Sharraf dan lain sebagainya. ${ }^{5}$

Di era digital 4.0 ini, pesantren merupakan tempat yang efektif untuk membentuk ketahanan mental santri. Mengingat tingkah laku/akhlaq genersi penerus bangsa yang menurun, sehingga sering ditemukan pada media cetak berita tentang perilaku yang menyimpang, atas perbuatan generasi penerus bangsa. Khususnya anak yang berada dalam masa puber serta belum memahami tentang agama Islam dan fenomena tersebut sering terjadi di sekolahan lanjutan pertama, karena kurang maksimalnya penerapan mata pelajaran agama Islam dan moral. Sebab itu generasi penerus mudah terjerumus pada perbuatan tindakan asusila. Keadaan serupa juga dapat menjadi sebab menurunnya moral, pergaulan bebas, penggunaan obat-obat terlarang, tindakan asusila, kriminalitas, dan berbagai bentuk kejahatan yang kebanyakan dilakukan oleh generasi muda yang belum memahami akhlak, kurangnya pendidikan akhlak serta pembinaan akhlak oleh orang tua pada anaknya.

Fenomena yang kedua, di era globalisasi saat ini terjadi kerentangan mental santri ketika berada di dalam kompleks pondok pesantren dibandingkan ketika mereka berada di luar kompleks pondok pesantren. Penanaman nilai-nilai pendidikan yang berupa aqidah dan akhlak terkikis oleh dunia luar dengan pergaulan bebas yang tidak bisa terkontrol, karena ketika mereka keluar dari kompleks pesantren, nilai-nilai pendidikan yang selalu ditanamkan ketika mereka berada di pesantren terkikis. Penyebab utamanya adalah karena tidak ada aturan pesantren yang perlu diperhatikan ketika berada di luar kompleks pesantren. Hal ini menyebabkan terkikisnya mental (jati diri) seorang santri ketika berada di lingkungan yang bebas.

Fenomena ini perlu diperhatikan agar implementasi nilai-nilai pendidikan pesantren tetap tertanamkan dalam mental seorang santri yang melanjutkan studinya di luar komples pesantren. Hal ini perlu ada organisasi yang membentuk kegiatan di pesantren untuk membantu mempertahankan mental (jati diri) santri agar tidak berdampak ke dalam perbuatan yang terlarang. Pada era globalisasi saat ini penamaman mental terhadap santri perlu ditingkatkan, karena banyak sekali terjadi kasus. Di saat santri keluar dari pondok pesantren ketahanan mental seorang

${ }^{5}$ Masyhud dkk, Manajemen Pondok Pesantren, (Jakarta: Diva Pustaka, 2003, hal. 2-3) 
santrinya berkurang, maka perlu peningkatan penanaman nilai-nilai pendidikan pesantren yang sangat ektensif kepada santri yang akan melanjutkan ke jenjang pendidikan yang ada di luar pesantren.

\section{Ekspansi Nilai-nilai Pendidikan di Pesantren}

Education is one important element in the development of a nation. Education is the largest field of investment in building and shaping mentality person. ${ }^{6}$ Dapat diartikan bahwa pendidikan adalah suatu pilar penting dalam pembangunan suatu bangsa. Pendidikan adalah bidang investasi terbesar dalam membangun dan membentuk mental seseorang, nilai-nilai pendidikan pesantren adalah konsep yang bersifat sederhana dan disetujui bersama, oleh masyarakat dengan baik, benar, berharga dan diinginkan. Nilai merupakan sesuatu hal yang diinginkan, dicita-citakan dan dianggap berpengaruh oleh masyarakat. Setiap masyarakat akan berpegang teguh pada nilai kebudayaan pesantren, dan disepakati oleh sebagian besar masyarakat. ${ }^{7}$

Pendidikan adalah suatu investasi penting dan tidak bisa dihilangkan dari kehidupan. Dengan pendidikan, ${ }^{8}$ bisa mengangkat ketahanan mental seseorang untuk menjadikan seseorang sosok yang tangguh dalam menghadapi perkembangan di era modern ini. Oleh karena itu, pendidikan pesantren dianggap oleh masyarakat sebagai tempat pendidikan Islam (islamic education) yang berkualitas, dengan model asrama. Santri mendapatkan pendidikan agama dengan pengajian atau madrasah yang sepenuhnya berada di bawah asuhan beberapa orang kiai dengan ciri khas yang bersifat kharismatik dalam segala hal. Hal ini pendidikan Islam berupaya meningkatkan harkat dan martabat serta menyiapkan kader penerus bangsa yang memiliki intelektualitas, spiritualitas dan akhlakul karimah, ${ }^{9}$ untuk membentuk ketahan mental santri.

${ }^{6}$ Syaiful Islam and others, 'To Boost Students Motivation and Achievement through Blended Learning, Journal of Physics: Conference Series, 2018.

${ }^{7}$ Somantri, M.I. Pendidikan Karakter: Nilai-nilai Bagi Upaya Pembinaan Kepribadian Bangsa.(Bandung; Widya Aksara Press, 2006), 45

${ }^{8}$ Akmal Mundiri, 'Strategi Lembaga Pendidikan Islam Dalam Membangun Branding Image', Pedagogik, 3.2 (2016), 58-72.

${ }^{9}$ Hasan Baharun, 'Pendidikan Anak Dalam Keluarga; Telaah Epistemologis', Pedagogik, 14.1 (2016), $57-63$. 
a. Pengertian Nilai-nilai Pendidikan Islam

Nilai adalah suatu tipe kepercayaan yang berada dalam ruang lingkup sistem kepercayaan dimana seseorang bertindak atau menghindari suatu tindakan, atau mengenai suatu yang pantas atau tidak pantas dikerjakan. Ini berarti berhubungan dengan pemaknaan atau pemberian arti suatu obyek. ${ }^{10}$ Oleh karena itu, nilai terdapat pada setiap pilihan yang dilakukan individu atau kelompok orang baik berkaitan dengan hasil (tujuan) maupun cara untuk mencapainya. Dalam hal ini terkandung pemikiran dan keputusan seseorang mengenai apa yang dianggap benar, baik atau diperbolehkan. ${ }^{11}$

Nilai-nilai penting untuk mempelajari perilaku organisasi karena nilai meletakkan fondasi untuk memahami sikap dan motivasi serta mempengaruhi persepsi kita. Individu-individu memasuki suatu organisasi dengan gagasan yang dikonsepsikan sebelumnya mengenai apa yang seharusnya dan tidak seharusnya. Soemantri mengklasifikasi nilai ke dalam empat macam: (1) nilai instrumental dan nilai terminal; (2) nilai instrinksik dan nilai ekstrinsik; (3) nilai personal dan nilai sosial; dan (4) nilai subyektif dan nilai obyektif. ${ }^{12}$

Selanjutnya, Spranger menjelaskan adanya enam orientasi nilai yang sering dijadikan rujukan oleh manusia dalam kehidupannya. Dalam pemunculannya, enam nilai tersebut cenderung menampilkan sosok yang khas terhadap pribadi seseorang. Karena itu, Spanger merancang teori nilai itu dalam istilah tipe manusia (the types of man), yang berarti setiap orang memiliki orientasi yang lebih kuat pada salah satu diantara enam nilai yang terdapat dalam teorinya. Enam nilai yang dimaksud adalah nilai teoretik, nilai ekonomis, nilai estetik, nilai sosial, nilai politik, dan nilai agama. ${ }^{13}$ Perilaku manusia sehari-hari pada dasarnya ditentukan, didorong atau diarahkan oleh nilai-nilai budayanya. ${ }^{14}$ Nilai yang dominan akan

10 Taliziduhu Ndraha, Teori Budaya Organisasi (Jakarta, PT. Rineka Cipta, 2005), 45.

11 Somantri, M.I. Pendidikan Karakter: Nilai-nilai Bagi Upaya Pembinaan Kepribadian Bangsa. (Bandung; Widya Aksara Press, 2006), 55.

12 Somantri, M.I. Pendidikan Karakter: Nilai-nilai Bagi Upaya Pembinaan Kepribadian Bangsa.(Bandung; Widya Aksara Press, 2006), 60.

${ }^{13}$ Chusnul Muali, Syaiful Islam, and Muhammad Mushfi El Iq Bali, 'Free Online Learning Based On Rich Internet Applications; The Experimentation Of Critical Thinking About Student Learning Style’, Journal of Physics: Conference Series, 1114 (2018), 1-6.

${ }^{14}$ Muhammad Mushfi El Iq Bali, 'Model Interaksi Sosial Dalam Mengelaborasi Keterampilan Sosial', Pedagogik, 4.2 (2017), 211-27. 
memunculkan perilaku yang dominan dalam kehidupan manusia yang membuat manusia berbudaya. Dalam kontek yang lebih mendasar, perilaku individu maupun masyarakat pada hakikatnya dipengaruhi oleh sistem nilai yang diyakininya. Sistem nilai tersebut merupakan jawaban yang dianggap benar mengenai berbagai masalah dalam hidup. ${ }^{15}$

Paradigma Islam pada dasarnya nilai merupakan akhlak, sedang akhlak merupakan ciri khas Islam untuk moral dan etika. Karena istilah nilai terkait dengan moral dan etika, maka antara moral, etika dan akhlak adalah satu kesatuan kata memiliki makna yang sama. ${ }^{16}$ Pengertian nilai dan pendidikan Islam dapat didefinisikan bahwa nilai-nilai pendidikan Islam adalah kumpulan dari prinsipprinsip hidup yang saling terkait yang berisi ajaran-ajaran guna memilihara dan mengembangkan fitrah manusia serta sumber daya manusia yang ada padanya menuju terbentuknya manusia seutuhnya (insan kamil) sesuai dengan ajaran Islam.

b. Bentuk Nilai-nilai Pendidikan Islam

Pokok-pokok nilai pendidikan Islam yang utama yang harus ditanamkan pada anak yaitu nilai pendidikan i'tiqodiyah, nilai pendidikan amaliyah, nilai pendidikan kbuluqiyah. ${ }^{17}$

1) Nilai Pendidikan I'tiqodiyah

Nilai pendidikan I'tiqodiyah ini merupakan nilai yang terkait dengan keimanan seperti iman kepada Allah SWT, malaikat, rasul, kitab, hari akhir dan takdir yang bertujuan menata kepercayaan individu. Iman berasal dari bahasa Arab dengan kata dasar amanayu'minu imanan artinya beriman atau percaya. ${ }^{18}$ Bukti-bukti keimanan diantaranya: (a) Mencintai Allah SWT dan Rasul-Nya, (b) Melaksanakan perintah-perintah-Nya, (c) Menghindari larangan-larangan-Nya, (d) Berpegang teguh kepada Allah SWT dan sunnah Rasul-Nya, (e) Membina hubungan kepada Allah SWT dan sesama manusia, (f) Mengerjakan dan meningkatkan amal shaleh, (g) Berjihad dan dakwah.

${ }^{15}$ Somantri, M.I. Pendidikan Karakter: Nilai-nilai Bagi Upaya Pembinaan Kepribadian Bangsa. (Bandung; Widya Aksara Press, 2006), 65.

${ }^{16}$ Ahmad Tafsir, Ilmu Pendidikan dan Perspektif Islam, (Remaja Rosda Karya, Bandung,2004), 74.

${ }^{17}$ Ahmad Tafsir, Ilmu Pendidikan dan Perspektif Islam, (Remaja Rosda Karya, Bandung, 2004), 93.

18 Ahmad Tafsir, Ilmu Pendidikan dan Perspektif Islam, (Remaja Rosda Karya, Bandung, 2004), 93. 
2) Nilai Pendidikan Amaliyah.

Nilai pendidikan Amaliyah merupakan nilai yang berkaitan dengan akhlaq atau tingkah laku. Nilai pendidikan amaliyah diantaranya:

a) Pendidikan Ibadah

Ibadah merupakan bukti nyata bagi seorang muslim dalam meyakini dan mempedomani aqidah Islamiyah. Pembinaan ketaatan beribadah kepada anak dimulai dari dalam keluarga. Sejak dini, anak-anak harus diperkenalkan dengan nilai ibadah, seperti diajarkan melafalkan surat-surat pendek dari Al-Qur'an untuk melatih lafal-lafal agar fasih mengucapkannya, karena membaca Al-Qur'an adalah ibadah. Kemudian juga anak-anak diajarkan mendirikan shalat, agar ketika anak mulai baligh, tidak perlu bersusah payah belajar shalat.

b) Pendidikan Muamalah

Pendidikan muamalah ialah pendidikan yang berkaitan antara manusia baik secara individu maupun kelompok. Pendidikan muamalah ini meliputi:

(1) Pendidikan Syakhsiyah, ialah pendidikan yang berkaitan dengan perilaku individu, seperti masalah perikahan, hubungan suami istri dan keluarga yang bertujuan untuk membangun keluarga yang sakinah, mawaddah dan sejahtera.

(2) Pendidikan Madaniyah, Pendidikan ini memuat tentang perdagangan seperti gaji, gadai yang bertujuan untuk mengelola harta benda hakhak indvidu atau kelompok.

(3) Pendidikan Jana'iyah, Pendidikan ini yang berhubungan dengan pidana atas pelanggaran yang dikerjakan oleh seseorang, yang bertujuan untuk keadilan sosial, baik berkaitan dengan harta benda, kehormatan, maupun hak-hak individu yang lain. Contoh: Pelanggaran HAM.

(4) Pendidikan Murafa'at, Pendidikan ini berhubungan dengan acara seperti peradilan, saksi maupun sumpah yang bertujuan untuk menegakkan keadilan diantara anggota masyarakat. Contoh: Pengadialan cerai, sengketa tanah, kasus pencurian dll. 
(5) Pendidikan Dusturiyah, Pendidikan ini berkaitan dengan undangundang negara yang mengatur hubungan rakyat dengan pemerintah yang bertujuan untuk stabilitas bangsa. Contoh: Mentaati peraturan aparat pemerintah.

(6) Pendidikan Duwaliyah, Pendidikan ini yang berhubungan dengan tata negara seperti tata negara Islam, tata negara tidak Islam, wilayah perdamaian dan wilayah perang, dan hubungan muslim di negara lain yang bertujuan untuk perdamaian dunia.

(7) Pendidikan Iqtishadiyah, Pendidikan ini berhubungan dengan perkonomian individu dan negara, hubungan yang miskin dengan yang kaya yang bertujuan untuk keseimbangan dan pemerataan pendapatan. Contoh: Memberikan sedekah kepada seorang fakir.

3) Nilai Pendidikan Khuluqiyah

Pendidikan ini merupakan pendidikan yang berkaitan dengan etika (akhlak) yang bertujuan membersihkan diri dari perilaku rendah dan menghiasi diri dengan perilaku terpuji. Contoh: Menghormati kepada orang yang lebih tua, dan menghargai orang yang lebih muda.

\section{Ketahanan Mental}

Ketahanan mental adalah kondisi kejiwaan yang bersifat dinamis yang mengandung kesanggupan untuk mengembangkan kemampuan dalam keadaan bagaimanapun juga, baik menghadapi gangguan dan ancaman dari luar keadaan dirinya sendiri. ${ }^{19}$ Ketahanan mental seorang santri dapat diketahui saat santri terjun dalam masyarakat atau ketika keluar dari pesantren. Pergaulan yang terbilang bebas, sedikit demi sedikit bisa mengikis ketahanan mental santri. Disebabkan banyak hal yang sangat menarik yang belum pernah dirasakan saat berada di pesantren. Gangguan-gangguan ini yang menyebabkan ketahanan mental santri menurun.

Mental berasal dari kata attitude (bahasa Inggris) yang bersumber dari kata personal (bahasa Latin) yang berarti kedok atau topeng. Maksudnya untuk menggambarkan perilaku, watak, atau pribadi/mental seseorang. Hal itu dilakukan

${ }^{19}$ Sudibyo Setyobroto, Training Mental (Jakarta: Solo Pres. 2001) hal. 53 
karena terdapat ciri-ciri yang khas yang hanya dimiliki oleh seseorang tersebut baik dalam arti kepribadian yang baik, ataupun yang kurang baik. ${ }^{20}$ Begitu juga dengan bangsa Arab mengatakan tingkah laku dengan istilah شخية yang bersumber dari kata yang berarti seseorang. Maka dari kedua istilah tersebut belum bisa menjawab apa arti dari mental karena masih terlalu umum dan kabur? Akan tetapi dalam bahasa Indonesia, ada satu istilah yang cukup menjawab, walau belum cukup jelas, yaitu istilah jati diri yang bermakna keadaan diri (sendiri) yang sesungguhnya (sejati). Disana kita dapat pengertian bahwa mental adalah karakteristik, tingkah laku sifat khas dari seseorang yang bersumber dari pengaruh yang diterima dari lingkungan, misalnya keluarga pada masa kecil, temen masa kecil dan juga bawaan seseorang sejak lahir. ${ }^{21}$

Mental seseorang akan berpengaruh terhadap akhlak, moral, budi pekerti, dan etika orang tersebut ketika berinteraksi dan berkomunikasi dengan orang lain dalam kehidupan sehari-hari di manapun ia berada. Artinya, sikap, tingkah laku, ajaran, dan nilai yang dimiliki akan menjadi landasan perilaku seseorang sehingga dapat membentuk budi pekertinya sebagai wujud ketahan mental orang itu. ${ }^{22}$ Selain itu, ketahan mental sering juga diartikan atau dihubungkan dengan ciri-ciri tertentu yang menonjol pada diri individu. Contohnya, kepada orang yang pemalu dikenakan atribut "mental pemalu", kepada orang yang super dikenakan atribut "mental super", dan kepada orang yang suka bertindak keras dikenakan atribut "mental keras".

Selain itu ,sering pula kita jumpai ungkapan atau sebutan "tidak bermental". Yang terakhir ini biasanya dialamatkan kepada orang-orang yang lemah, plin-plan, pengecut, dan semacamnya. ${ }^{23}$ Secara umum, kepribadian dapat diartikan sebagai keseluruhan kualitas perilaku individu yang merupakan ciri khas dalam berinteraksi dengan lingkungannya. ${ }^{24}$ Jadi, kepribadian santri adalah sifat khas dari diri seorang santri yang bersumber dari lingkungan, yang akan berpengaruh terhadap akhlak, moral, budi pekerti, dan etika santri tersebut.

\footnotetext{
20 Agus Sujanto, Psikologi Kepribadian, (Semarang: Bumi Akasara, 2006), h. 189.

21 Ahmad Daes, Konsep Kepribadian Dalam Al-Quran dan Hadits, (Jakarta: t.p., 1989), h. 9.

22 Ahmad Daes, Konsep Kepribadian Dalam Al-Quran dan Hadits, (Jakarta: t.p., 1989), h. 9.

${ }^{23}$ Koswara, Teori-Teori Kepribadian, (Bandung: Eresco, 1991), h. 10.

${ }^{24}$ Tohirin, Psikologi Pembelajaran Pendidikan Agama Islam, (Jakarta: PT Raja Grafindo Persada, 2005), h. 169.
} 


\section{Problematika Mental Santri}

Menurunnya mental santri seringkali nampak jika seorang santri telah berada di luar lingkungan pondok pesantren. Mereka yang dulunya patuh dengan aturan karena takut di sanksi, ketika berada di luar pondok pesantren mereka sudah tidak patuh dengan aturan itu lagi. Hal ini yang menjadi problematika menurunnya ketahanan mental seorang santri. Nilai-nilai pendidikan yang ditanamkan saat di pesantren seakan hilang akibat pergaulan bebas di dunia baru. Hal ini perlu ada penanaman mental kepada santri yang melanjutkan jenjang pendidikan di luar pesantren. Oleh karena itu, pentingnya diskusi dengan sesama santri dan saling mengingatkan tentang nilai-nilai pesantren yang telah ditanamkan semasa di pesantren harus terus direnungkan oleh seorang santri meskipun mereka berada di luar kompleks pondok pesantren.

Aturan-aturan yang seharusnya dipatuhi saat di pesantren seharusnya tetap dipatuhi ketika mereka keluar dari pesantren. Semisal, menjaga pertemuan selain mahrom, mengkonsumsi barang haram dan pergaulan bebas yang sering terjeremus ke dalam perzinaan. Seolah telah hilang dibenak pikiran seorang santri ketika mereka keluar dari pondok pesantren. Nilai-nilai keagamaanpun di saat santri keluar dari pesantren banyak yang terkikis oleh pergaulan. Semisal di saat santri berada di pesantren mereka selalu istiqomah dalam melaksanakan ibadah dan belajar. Kebiasaan ini hilang karena pergaulan yang salah ketika di luar kompleks pondok pesantren. Di zaman saat ini seorang santri yang berada di luar pondok pesantren kehilangan jati dirinya untuk melaksanakan ke istiqomahan dalam beribadah.

\section{Tujuan Pembentukan Mental Santri}

Sebagian besar perkembangan mental manusia merupakan produk pengalaman pribadi yang diperoleh dalam suatu kelompok, nilai, norma, dan kenyakinan yang ada dalam kelompok juga membantu terbentuknya mental santi. Tanpa pengalaman suatu kelompok itu, mental santri tidak akan berkembang. Meskipun para individu yang memiliki karakter sama, menjadi anggota kelompok yang sama, pengalaman mereka dalam kelompok tersebut tidak akan sama. 
Perbedaan pengalaman inilah yang membentukhi variasi mental santri dalam batasbatas tertentu. ${ }^{25}$

Maka para pengasuh pesantren, sebagai ulama pewaris para Nabi, terpanggil untuk meneruskan perjuangan Nabi Muhammad SAW dalam membentuk ketahanan mental masyarakat melalui para santrinya. Para pengasuh pesantren mengharapkan santri-santrinya memiliki integritas ketahanan mental yang tinggi (shalib). Tujuan lain pembentukan ketahanan mental santri agar dengan ilmu agamanya mereka sanggup menjadi mubaligh yang menyebarkan ajaran Islam dalam masyarakat sekitar melalui ilmu dan amalnya. ${ }^{26}$

\section{Proses Pembentukan Mental Santri}

Islam adalah agama yang lurus mengajarkan pemeluknya untuk senantiasa melakukan perintah dan menjauhi larangan-Nya yang didasarkan pada al-Quran dan Hadis. Hal itu dapat dilihat dari bagaimana seseorang yang mengaku sebagai muslim yang baik akan selalu berusaha melakukan perbuatan yang didasarkan pada nilai-nilai Islam menjadi pilihan dalam bagaimana seorang muslim bercermin.

Tingkah laku manusia itu banyak yang dibentuk oleh kebiasaan-kebiasaan yang berlangsung dalam waktu yang lama secara terus-menerus. Karena kebiasaan itu akan bisa menjadikan segala sesuatu itu menjadi mudah. Pembiasaan (babituation) seseorang dalam waktu lama secara terus menerus, misalnya: omongan yang baik, tingkah laku yang sopan dan lembut, atau sebaliknya yang kasar, jorok atau kotor, menyakitkan hati dan lain sebagainya. Pembentukkan mental pada dasarnya adalah upaya untuk mengubah sikap-sikap ke arah nilai-nilai keislaman. Pembentukan mental berlangsung secara bertahap, tidak sekali jadi, melainkan sesuatu yang berkembang. Oleh karena itu, pembentukan mental itu sendiri merupakan proses. ${ }^{27}$

Idealisasi out-put santri menjadi seorang yang alim shalih kemudian diterjemahkan dalam penempatan cara hidup, nilai, dan prinsip hidup sehari-hari di pesantren. Nilai-nilai tersebut membentuk tingkah laku (akhlaq) santri yang kemudian menumbuhkan nilai-nilai pesantren dalam jati dirinya, seperti keikhlasan,

25 Ujam Jaenudin, Psikologi Kepribadian, (Bandung: Pustaka Setia, 2012), h. 188.

${ }^{26}$ Yasin, Dimensi-Dimensi Pendidikan Islam. (Malang: UIN-Malang Press, 2008) h. 243

27 Ramayulis, Ilmu Pendidikan Islam, (Jakarta: Kalam Mulia, 2002), h. 195. 
kesederhanaan, kemandirian, dan keteladanan yang telah sangat lama dipraktikkan di pesantren dan menjadi ciri khas. Seorang Kiai, misalnya, harus rela membuka pintu rumahnya 24 jam untuk melakukan fungsi pelayanan masyarakat. Ini contoh konkrit dari prinsip keikhlasan yang diteladankan kepada para santrinya.

Sikap hidup tanpa pamrih atau dalam bahasa pesantrennya "illahi ta" ala" ini menjadikan pesantren mampu bertahan hidup sampai berabad-abad lamanya. Generalisasi ikhlas dalam menuntut ilmu juga dapat diartikan sebagai kesungguhan dan keseriusan dalam belajar. Selama belajar itu santri mengesampingkan kegiatankegiatan yang tidak relevan dan bahkan kesenangan sesuai selera pribadinya. Sikap hidup ini lebih menekankan pada proses daripada hasil. Implikasinya adalah para santri menjadi individu yang tangguh, berjiwa besar, dan tidak takut menghadapi kenyataan pahit dalam hidupnya. ${ }^{28}$

Prinsip ikhlas ini juga didorong dengan prinsip kesederhanaan. Pola hidup sederhana tampak mulai dari cara santri menggunakan pakaian, menyediakan makanan dan minuman sederhana. Sederhana bukan berarti kekurangan, namun pola hidup sederhana itu tidak berlebihan, meskipun banyak barang dan makan mewah yang bisa dibeli dengan uang yang halal. Prinsip hidup sederhana ini juga terlihat pada nilai yang berkembang dari seseorang, yaitu selalu hidup sabar, tawakkal, zuhud dan wira'i. ${ }^{29}$

Semakin matang sistem keyakinan dan pola pikir yang terbentuk, maka semakin jelas tindakan, kebiasaan, dan kepribadian unik dari masing-masing individu. Dengan kata lain, setiap seseorang akhirnya memiliki sistem keyakinan (belief system), citra diri (self-image), dan kebiasaan (babit) yang unik. Jika sistem kepercayaannya benar dan selaras, kepribadiannya baik, dan konsep dirinya bagus, maka kehidupannya akan terus baik dan semakin membahagiakan. Sebaliknya, jika sistem kepercayaan tidak selaras, kepribadiannya tidak baik, dan konsep dirinya buruk, maka kehidupannya akan dipenuhi banyak permasalahan dan penderitaan. ${ }^{30}$

\footnotetext{
${ }^{28}$ Muhammad Mushfi El Iq Bali and Lailatur Rohmah, 'Implementasi Pendekatan Eklektik Berbasis Sharing Zone', Murobbi: Jurnal Ilmu Pendidikan, 6.2 (2018), 152-67.

${ }^{29}$ Nafi', dkk Praksis Pembelajaran Pesantren. (Yogyakarta: Instite for Training and Development (ITD), 2007)

30 Abdul Majid dan Dian Andayani, Pendidikan Karakter Perspektif Islam, (Bandung: PT Remaja Rosdakarya, 2011), h. 18.
} 
Pesantren juga memiliki Trilogi dan Panca Kesadaran Santri, agar santrisantri bisa membangun mentalnya sendiri. Trilogi santri meliputi; pertama memperhatikan kewajiban fardlu 'ain, kedua, mawas diri dengan meninggalkan dosadosa besar, dan ketiga berakhlak baik kepada Allah dan Makhluk. ${ }^{31}$ Selanjutnya ada pula kesadaran-kesadaran yang harus selalu diterapkan oleh seorang santri. Kesandaran ini terangkum dalam Panca Kesadaran Santri, meliputi; 1. Kesadaran Beragama, 2. Kesadaran Berilmu, 3. Kesadaran Bermasyarakat, 4. Kesadaran Bebangsa dan Bernegara, 5. Kesadaran Berorganisasi. ${ }^{32}$ Ketika seorang santri tetap berkomitmen dengan trilogi dan panca kesadaran santri, ketika seorang santri hidup diluar pesantren maka seorang santri akan teguh mentalnya dan mempertahankan kepribadiannya seperti layaknya santri.

\section{Kesimpulan}

Pendidikan adalah prioritas utama dalam meningkat kepribadian, karakter, dan mental seseorang. Di era globalisasi ini pendidikan yang sangat kuat untuk membentuk kepribadian, karakter, dan mental seseorang adalah pendidikan pesantren. Nilai-nilai pendidikan yang begitu komplek dari nilai, aqidah, tauhid, akhlaq dan ilmu sains di era globalisasi ini sudah terpenuhi di pondok pesantren. Semisal pembiasaan dalam sistem keyakinan, citra diri, kebiasan terus diterapkan dalam lingkungan pesantren sehingga membentuk mental santri lebih baik dan teruss membaik dengan adanya pembiasaan dan penerepan nilai-nilai pendidikan pesantren. Dengan menerapkan pendidikan yang berbasis asrama dengan membatasi pertemuan antara laki-laki dan perempuan sangat membantu generasi muda untuk fokus belajar dan mencari jati dirinya agar memiliki kepribadian, karakter, dan mental yang tangguh.

\footnotetext{
${ }^{31}$ K.H. Hefni Razaq, dkk, Selayang Pandang Pondok Pesantren Nurul Jadid (Probolinggo, Bagian Humas dan Protokuler PPNJ, 2016) h. xv

32 K.H. Hefni Razaq, dkk, Selayang Pandang Pondok Pesantren Nurul Jadid (Probolinggo, Bagian Humas dan Protokuler PPNJ, 2016) h. xiv
} 


\section{DAFTAR PUSTAKA}

Baharun, Hasan, 'Pendidikan Anak dalam Keluarga; Telaah Epistemologis', Pedagogik, 3.2 (2016).

Bali, Muhammad Mushfi El Iq, 'Model Interaksi Sosial dalam Mengelaborasi Keterampilan Sosial', Pedagogik, 4.2 (2017), 211-227.

_ $1-14$.

Bali, Muhammad Mushfi El Iq, and Lailatur Rohmah, 'Implementasi Pendekatan Eklektik Berbasis Sharing Zone', Murobbi: Jurnal Ilmu Pendidikan, 6.2 (2018), 152-167.

Daes, Ahmad. 2006. Konsep Kepribadian dalam al-Quran dan Hadit's. Jakarta: Rajagrafindo Persada.

Islam, Syaiful, Hasan Baharun, Chusnul Muali, Moh Idil Ghufron, and Ismail. Bali, Muhammad Mushfi El Iq, Wijaya, Mualim and Marzuki, 'To Boost Students 'Motivation and Achievement through Blended Learning', Journal of Physics: Conference Series, 2018.

Jaenudin, Ujam. 2012. Psikologi Kepribadian. Bandung: Pustaka Setia.

Koswara. 1991. Teori-teori Kepribadian. Bandung: Eresco.

Majid, Abdul \& Andayani, Dian. 2011. Pendidikan Karakter Perspektif Islam. Bandung: PT Remaja Rosdakarya.

Muali, Chusnul, Syaiful Islam, and Muhammad Mushfi El Iq Bali, 'Free Online Learning Based On Rich Internet Applications; The Experimentation Of Critical Thinking About Student Learning Style', Journal of Physics: Conference Series, 1114 (2018), 1-6.

Mundiri, Akmal, 'Strategi Lembaga Pendidikan Islam Dalam Membangun Branding Image', Pedagogik, 3 (2016), 58-72.

Munif, Muhammad, 'Pengembangan Pendidikan Agama Islam', 3.2 (2015), 46-57.

Nafi', dkk. 2007. Praksis Pembelajaran Pesantren. Yogyakarta: Instite for Training and Development (ITD).

Ndraha, Taliziduhu. 2005. Teori Budaya Organisasi. Jakarta: PT. Rineka Cipta.

Ramayulis. 2002. Ilmu Pendidikan Islam. Jakarta: Kalam Mulia.

Razaq, Hefni dkk. 2016. Selayang Pandang Pondok Pesantren Nurul Jadid. Probolinggo: Bagian Humas dan Protokuler PPNJ.

Robins, Stephen P. 1995. Perilaku Organisasi. Jakarta: PT. Prenhallindo.

Setyobroto, Sudibyo. 2001. Mental Training. Jakarta: Solo Pres.

Somantri, M. I. 2006. Pendidikan Karakter: Nilai-nilai bagi Upaya Pembinaan Kepribadian Bangsa. Bandung: Widya Aksara Press.

Sujanto, Agus. 2006. Psikologi Kepribadian. Semarang: Bumi Akasara.

Tafsir, Ahmad. 2004. Ilmu Pendidikan dan Perspektif Islam. Bandung: Remaja Rosda Karya.

Tohirin. 2005. Psikologi Pembelajaran Pendidikan Agama Islam. Jakarta: PT Raja Grafindo Persada.

Yasin. 2008. Dimensi-dimensi Pendidikan Islam. Malang: UIN-Malang Press. 